\title{
LEARNING-BY-EXPORTING OR MANAGERIAL QUALITY? EVIDENCE FROM THE CZECH REPUBLIC
}

\section{Branislav Saxa}
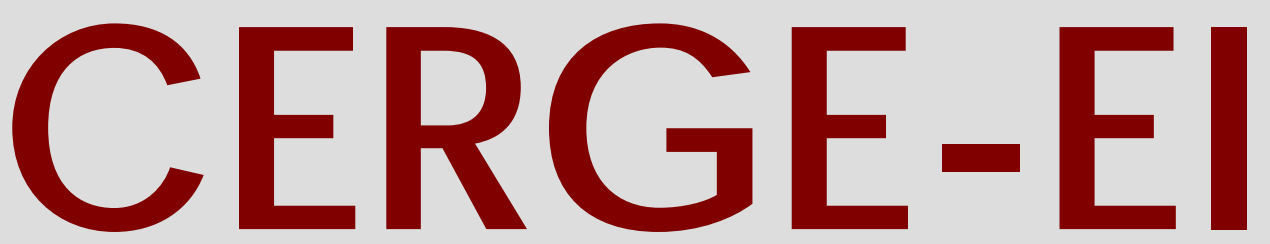

Charles University Centerfor Economic Research and Graduate Education Academy of Sciences of the Czech Republic Ec onomic s Institute 


\title{
Working Paper Series 358 (ISSN 1211-3298)
}

\section{Learning-by-Exporting or Managerial Quality? \\ Evidence from the Czech Republic}

\author{
Branislav Saxa
}

CERGE-EI

Prague, August 2008 
ISBN 978-80-7343-158-7 (Univerzita Karlova. Centrum pro ekonomický výzkum a doktorské studium)

ISBN 978-80-7344-147-0 (Národohospodářský ústav AV ČR, v.v.i.) 


\title{
Learning-by-Exporting or Managerial Quality? Evidence from the Czech Republic
}

\author{
Branislav Saxa ${ }^{+}$ \\ CERGE-EI* and Czech National Bank
}

\begin{abstract}
This paper employs firm-level panel data from the Czech Republic to investigate the empirical relevance of the learning-by-exporting hypothesis. To provide convincing estimates, one must be able to disentangle learning-by-exporting from changes in company management that induce the company to both start exporting and introduce productivity increasing measures. Therefore, I compare estimates based on matching on propensity score, which do not control for potential management changes, to estimates based on an instrumental variables strategy. Specifically, I focus on firms that start exporting due to changes in the industry-specific exchange rate and industry-specific ratio of producer prices on domestic and foreign markets. The results suggest that learning-by-exporting in the Czech Republic is not significant, either statistically or economically, irrespective of the method used.
\end{abstract}

\begin{abstract}
Abstrakt
Táto štúdia skúma empirickú relevanciu hypotézy o učení sa exportovaním s využitím firemných panelových dát z Českej republiky. Pre poskytnutie presvedčivých odhadov je potrebné oddelit' efekty učenia sa exportovaním od efektov zmien $\mathrm{v}$ manažmente, ktoré majú za následok paralelný vstup firmy na zahraničné trhy a prijatie opatrení zvyšujúcich produktivitu firmy. Preto sú v štúdii porovnávané výsledky získané metódou matching on propensity score, ktoré môžu byt' ovplyvnené zmenami v manažmente s výsledkami získanými s využitím inštrumentálných premenných. Kvôli oddeleniu týchto efektov sa v štúdii sústred'ujem na firmy, ktoré začínajú $\mathrm{s}$ exportom v reakcii na zmeny odvetvovo špecifického výmenného kurzu a zmeny pomeru cien domácich a zahraničných výrobcov. Výsledky štúdie naznačujú, že $\mathrm{v}$ prípade českých exportérov nie sú efekty učenia sa exportom signifikantné ekonomicky ani štatisticky, bez ohl'adu na použitú metódu.
\end{abstract}

Keywords: exporting, productivity, matching on propensity score, local average treatment effect JEL classification: D24, D83, F13, F14-15, C23

\footnotetext{
+ Email: branislav.saxa@cerge-ei.cz. The author would like to thank Jan Hanousek, Stepan Jurajda, Randall Filer, Stephen R. Yeaple and two anonymous referees for helpful comments and suggestions. The paper has also benefited from discussions at the Spring Meeting of Young Economists (2008) and the DIME conference on "Knowledge in Space and Time" (2008). The financial support of the Grant Agency of the Charles University, Grant No. $325 / 2006$ and GACR, Grant No. 402/06/1293 is gratefully acknowledged. The views expressed in this paper are not necessarily those of affiliated institutions.

* A joint workplace of the Center for Economic Research and Graduate Education, Charles University, and the Economics Institute of the Academy of Sciences of the Czech Republic.

Address: CERGE-EI, P.O. Box 882, Politických vězňů 7, Prague 1, 111 21, Czech Republic.
} 


\section{Introduction}

Exporters are more productive than non-exporters. Empirical evidence for this claim can be found in numerous recent studies, ${ }^{1}$ though causality in the relationship is not that clear. There are two main non-exclusive theories which attempt to explain these findings. The first, often referred to as the self-selection theory, proposes that more productive firms self-select into exporting due to the existence of sunk costs connected with entering foreign markets ${ }^{2}$ and possibly stronger competition on foreign markets. The second theory, referred to as the learning-by-exporting theory, suggests that exporting firms enhance their productivity through selling abroad. This can happen in several ways. Exporters can learn from foreign customers, they can increase productivity due to the pressure of international competition, or they can simply gain new markets and benefit from economies of scale. In terms of causality, there is a clear distinction between the two theories. According to the self-selection theory, causality indicates that higher productivity leads to exporting. On the contrary, the learning-by-exporting theory argues that exporting enhances productivity. To reiterate, these two theories are non-exclusive, i.e., more productive firms can selfselect into exporting but, at the same time, the productivity of exporters can grow faster than the productivity of non-exporters.

The power of the second theory becomes clearer if the domestic economy is less developed and relatively small. For a less developed country, the greater difference in technology levels between domestic and foreign firms increases the possible

\footnotetext{
${ }^{1}$ See, for example, Bernard and Jensen (1999), Clerides, Lach and Tybout (1998), Bernard and Wagner (1998), Castellani (2001), Aw, Chung and Roberts (2000), Head and Ries (2003), Pavcnik (2002), and Arnold and Hussinger (2005).

${ }^{2}$ The existence of sunk costs was empirically confirmed in several studies starting with Roberts and Tybout (1997).
} 
productivity gains that exporting firms can achieve through contacts with more developed foreign partners. In other words, a firm in a less developed country has a greater potential to learn by exporting than does a firm in an advanced country. Further, a firm operating in a small country can substantially increase its sales by entering foreign markets. If such a firm can benefit from economies of scale, the second theory gains even stronger merit.

While empirical studies unanimously ${ }^{3}$ confirm the first direction of causality, i.e., that more productive firms self-select themselves into exporting, empirical evidence on the second direction, i.e., learning-by-exporting, is ambiguous. Learning-by-exporting was rejected in the cases of the USA, Germany, Taiwan, Korea, Colombia, Mexico and Morocco; learning effects were found in China, some African countries, and to some extent Spain ${ }^{4}$ and Italy.

Motivation for this paper is built on the expectation that exporters from transition countries in Central and Eastern Europe (CEE) could gain substantially in terms of productivity. One reason is the initial technological gap between domestic and foreign firms (mainly those from Western Europe, where a major part of exports were directed soon after the collapse of $\mathrm{COMECON}^{5}$ ) at the beginning of transition. The catch-up process generally implies strong growth in productivity. In the presence of heavy productivity gains in general, the difference in productivity gains between exporting and non-exporting firms could be more pronounced. Therefore, if learningby-exporting exists, it should be more significant in transition countries than in

\footnotetext{
${ }^{3}$ To my knowledge, no paper investigating the hypothesis that firms self-select into exporting rejects that hypothesis.

${ }^{4}$ Delgado, Farinas and Ruano (2002) do not find significant learning effects for the whole sample, but only for a sub-sample of young firms in Spain.

${ }^{5}$ Council for Mutual Economic Assistance was an economic organization of communist countries.
} 
countries with benign productivity growth.

Besides searching for evidence of learning-by-exporting in the similar way as previous studies did using firm-level data in other countries, I also address the following: Does simultaneous occurrence of the beginning of exporting and productivity gains confirm the validity of the learning-by-exporting theory or can it be a consequence of other factors, e.g. change in management? In a typical situation, a new manager takes charge of a non-exporting manufacturing firm. The fact that the firm did not export before the new manager takes control does not have to be necessarily related to the productivity of the firm. Firm could have not exported its products because the previous manager had no experience with exporting in general or because the manager was not willing to undergo the risk of entering foreign markets. On the contrary, the new manager might have past experience with exporting and can recognize the firm's exporting potential or might be less risk averse and eager to start with exporting. At the same time, the new manager can recognize opportunities to increase productivity and adopt measures to boost it. It might well be that these opportunities existed before, however, the previous manager did not identify them or simply preferred to maintain the status quo. As a result, two changes can be observed in a firm-level data of the considered firm: export entry and productivity increase. In the described typical situation, both are the consequence of the new manager taking charge of the firm. Increased productivity does not have to be a necessary condition for entering foreign markets and, vice versa, observed productivity enhancements are not a result of exporting. However, researchers identifying an occurrence of both changes at the same time or with a lag are likely to argue in favor of the learning-by-exporting hypothesis. Since a change in management 
is typically not observable in firm-level data, it is not feasible to directly test the relevance of the described situation empirically. To disentangle learning-by-exporting from explained simultaneous changes in export and productivity induced by a new manager, I employ the movements of exchange rates and producer prices as exogenous factors that can motivate a firm to start to export.

In addition, controlling for ownership can have a serious impact on the empirical results of testing the learning-by-exporting hypothesis. The line of reasoning is as follows: If firms owned by a foreign owner have access to technology directly from the foreign owner, their potential to increase productivity through exporting is limited. On the other hand, exporting may form an important channel of productivity gains for domestic firms that do not have the possibility to acquire productivity-enhancing knowledge from a foreign owner. Therefore, pooling domestic and foreign-owned firms together can conceal the effect of learning-by-exporting.

This paper thus contributes to the existing literature in two ways. First, by testing the learning-by-exporting hypothesis on data from the Czech Republic, a representative of the CEE region. Regarding the growth of productivity and the importance of exports, ${ }^{6}$ the CEE region is unique among those economies for which similar research is available. Second, the study suggests an approach that is focused on firms that start to export due to exogenous factors. Therefore, I am able to eliminate the cases of a simultaneous rise of productivity and start of exporting due to the case of firm with new management, which launch exporting and apply measures boosting productivity at the same time.

\footnotetext{
${ }^{6}$ Openness of the Czech economy, defined as (Export + Import)/GDP, reached 110\% in 2000, placing the Czech Republic among the most open economies in Europe.
} 
The remainder of the paper is organized as follows. Related literature and available empirical results are described in the next section. The methodology is outlined in section three. The fourth section describes the data, and the results are discussed in the fifth section. Section six deals with robustness issues and section seven concludes.

\section{Literature Review}

While most empirical studies support the self-selection theory, limited evidence exists that validates the learning-by-exporting theory. One pioneering paper is that of Clerides, Lach and Tybout (1998), who employ firm-level data from Colombia, Mexico and Morocco and confirm the self-selection theory, but find little support for the learning-by-exporting theory. ${ }^{7}$ The significance of self-selection but lack of evidence for learning-by-exporting is confirmed by Bernard and Jensen (1999) for U.S. firms and by Arnold and Hussinger (2004) for German firms. Isgut (2001) shows that exporters are larger, have higher labor productivity, and pay higher wages three years before entering foreign markets but that labor productivity doesn't grow faster in exporting firms after they start exporting. Delgado, Farinas and Ruano (2002) find evidence supporting self-selection in Spanish data and some support for learning-byexporting, albeit limited to young exporters.

Results consistent with the learning-by-exporting theory can be found in Girma, Greenway and Kneller (2002) for U.K. firms, or in the study of firms from four African countries performed by Bigsten et al. (2004). Castellani (2002) in his study employing data on Italian firms finds that exporting status itself has no effect on

\footnotetext{
${ }^{7}$ Some learning was found in the case of Morocco.
} 
productivity but that productivity growth is positively related to export intensity. Focusing on labor productivity only, Wagner (2002) uses German firms to show that exporting has positive effects on labor productivity growth. Finally, Bleaney, Filatotchev and Wakelin (2000) test the learning-by-exporting hypothesis for Belarus, Russia and Ukraine, and yield results in support of the learning-by-exporting theory. However, caution is called for here since the authors use the number of employees as the only measure of productivity. Moreover, the used sample is rather small ("roughly 75 from each of the three countries") and likely not representative.

In addition to the self-selection and learning-by-exporting theories, HallwardDriemeier, Iarossi and Sokoloff (2002) propose an alternative explanation for a correlation between export and productivity. They argue that firms entering foreign markets do not show higher productivity due to an exogenous productivity shock, but rather as a result of their past decision to enter foreign markets and subsequent decisions aimed at increasing productivity. The authors use survey data from five Asian countries to assess the appropriateness of their theory. Comparing information on firms already exporting in the first year of their existence with firms that start exporting only later, the authors find support for their view. Based on their results, they argue that expansion of export opportunities in less developed countries could increase the incentives of firms to export, and consequently to increase their productivity.

Different results from different studies do not necessarily have to be attributed to country specifics only. In terms of methodology, the studies mentioned above employ a variety of approaches. Two main features can influence the results of causality 
described above: the method used to measure productivity and the estimation strategy. As for measuring productivity, measures of total factor productivity (TFP) based on different production functions are employed in several cases (e.g., Bigsten et al. (2004) use TFP based on Translog and Cobb-Douglas production functions; Girma, Greenaway and Kneller (2004) use TFP based on Cobb-Douglas production function, etc). Arnold and Hussinger (2004) use the Olley and Pakes (1996) two-step semiparametric procedure to control for the simultaneity problem in TFP estimation. Clerides, Lach and Tybout (1998) proxy productivity by average variable costs and labor productivity. Finally, as mentioned earlier, Bleaney, Filatotchev and Wakelin (2000) use employment as the only measure of performance, due to the impossibility of using monetary measures stemming from the presence of high inflation.

Estimation strategies differ from paper to paper as well. Clerides, Lach and Tybout (1998) use panel data to estimate a system of two equations - one for participation in export markets and one for the process governing their productivity measure. Consequently, they use GMM to estimate the system and test both self-selection and learning-by-exporting hypotheses. Bigsten et al. (2004) use maximum likelihood as well as GMM estimation in a setup similar to the one of Clerides, Lach and Tybout (1998). Due to the lack of available time series, Castellani (2002) opts for a crosssection estimation of two separate equations for export participation and TFP growth. In addition to export participation, Castellani (2002) proposes a model with an export intensity equation, estimated by tobit due to values censored both from left and right (at 0 and 1). Girma, Greenway and Kneller (2004) as well as Wagner (2002) use a matching approach to test for direction of causality. Further, Arnold and Hussinger (2004) exploit both the matching approach and the concept of Granger causality. 
Finally, Delgado, Farinas and Ruano (2002) use non-parametric tests to test the selfselection and learning-by-exporting hypotheses.

\section{Methodology}

My main objective is to estimate the effects of export entry on a firm's productivity. In this section, the estimation of productivity measures is described first. Consequently, two approaches adopted in the estimation of the effect of export entry on productivity are explained: matching on propensity score and regression analysis. While matching on propensity score is more robust to model misspecification, regression analysis in the instrumental variable setting enables me to estimate the effect of export entry on the productivity of these firms that entered foreign markets due to an exogenous impetus.

\subsection{Productivity Measures}

Three productivity measures are employed to evaluate productivity developments at the firm level: labor productivity based on output, labor productivity based on value added and total factor productivity utilizing a methodology suggested by Levinsohn and Petrin (2000).

Labor productivity based on output is defined as output divided by labor (see Table 1 for the definitions of underlying variables). Labor productivity based on value added is defined as value added divided by labor. Total factor productivity is defined as the residual from the Cobb-Douglas production function. Compared to labor productivity, 
total factor productivity has an advantage of taking into account additional inputs, not only labor. However, it has its drawbacks, too. One of them is the reliability of data on capital stock, which is particularly disturbing in the firm-level data statistics of transition countries. The other problem is the residual nature of total factor productivity estimation and its problematical interpretation. Due to the different nature of labor productivity and total productivity measures, it is not possible to compare the results based on these two approaches directly. To address the simultaneity problem in the input choice, I use the approach suggested by Levinsohn and Petrin (2000) to estimate total factor productivity. ${ }^{8}$ Simultaneity problem stems from the fact that at least part of the firm's productivity can be observed by the management before the decision about factor inputs is taken. But then the error term of the productivity estimation equation is correlated with the inputs, i.e., explanatory variables. This leads to an estimation bias. Levinsohn and Petrin (2000) suggest a methodology that employs the data on intermediate inputs that addresses the problem of simultaneity.

The productivity of export starters and non-exporters is compared in terms of levels and growth rates. In the level version, the productivity of each firm in each year is recomputed vis-à-vis the average productivity in the group of firms from the same 2digit industry, same size group ${ }^{9}$ and same year, where the average productivity is set to 100. The whole population of firms is used in the group comparison (not only export starters and non-exporters). It is important to note that although such an

\footnotetext{
${ }^{8}$ Total factor productivity estimation is implemented in STATA using the levpet procedure suggested by Petrin, Poi and Levinsohn (2004). The revenue version was used with materials as a proxy variable. Revenues, capital stock and materials were deflated using industry specific producer price indexes. Logarithms of all variables were used in the estimation.

${ }^{9}$ Firms are divided into four size groups based on the number of employees recomputed on an eight hour day basis.
} 
approach makes productivity more comparable across firms, the productivity time series for a single firm becomes inconsistent. Productivity growth rates are year-onyear growth rates of original productivity levels without within group comparison.

\subsection{Matching on Propensity Score}

Matching on propensity score is not a new approach in the literature on learning-byexporting (see Wagner 2001, Girma, Greenaway and Kneller 2004, Arnold and Hussinger 2005). The idea is to match two otherwise similar firms with one difference - one of the firms starts with exporting, the other remains on the domestic market only. The two firms have to be matched in the year preceding the year when the exporter begins exporting. The outcome of interest, in this case the productivity measure, is then compared between the groups of export starters and non-exporting firms.

Matching on propensity score is implemented using the Stata command psmatch2, described in detail in Leuven and Sianesi (2003). Matching is based on the probability of firms starting to export given the covariates. The choice of covariates is motivated by two goals. First, covariates should well predict the exporting status of a firm. For this reason, I consider variables that appear as significant explanatory variables in the previous research on exporting behavior. Second, as Caliendo and Kopeinig (2005) note, using a large set of covariates might lead to high variance of estimated effects; therefore I tend toward a more parsimonious set of covariates. In this case, labor, investments, revenues, industry-specific exchange rates and industry-specific ratio of 
producer prices are used as covariates. I opt for one-on-one matching with common support $^{10}$ and logit function used for estimation.

\subsection{Regression Analysis and Local Average Treatment Effect}

In addition to estimating average treatment effect using matching on propensity score, regression analysis is employed. Specifications estimated on the sample of nonexporters and export starters are described below. First, I estimate the effect of exporting on the productivity measure using a fixed effect estimator:

$$
\text { productivity }_{i, t}=\beta_{0}+\beta_{1} \text { firstyear }_{i, t}+\beta_{2} \ln l_{i, t-1}+\beta_{3} \ln k_{i, t-1}+\delta \text { controls }_{i, t}+\alpha_{i}+\varepsilon_{i t}
$$

where productivity $_{i, t}$ is a selected productivity measure of the firm $i$ in the year $t$, firstyear $_{i, t}$ is a dummy variable equal to 1 if the firm $i$ exports in the year $t$, but does not export in the year $t-1$. Variables $l$ and $k$ denote labor and capital, and controls $_{i, t}$ include year dummies that are supposed to capture time-varying effects common for all firms. To avoid simultaneity issues stemming from the fact that some of the explanatory variables enter the productivity estimation in the first step, labor and capital enter the estimation equation (1) with the lag of one year. Finally, $\alpha_{i}$ is a firm fixed effect and $\varepsilon_{i t}$ is the error term. Firm fixed effects control for time-invariant productivity differences between firms. To capture the correlation between the productivity and export decision one year before and one year after starting to export, I also estimate (1) with a lag and lead on firstyear:

\footnotetext{
${ }^{10}$ Common support means that treatment observations whose propensity score is higher than the maximum or less than the minimum propensity score of the controls are dropped.
} 
productivity $_{i, t}=\beta_{0}+\beta_{1}$ firstyear $_{i, t+1}+\beta_{2} \ln l_{i, t-1}+\beta_{3} \ln k_{i, t-1}+\delta$ controls $_{i, t}+\alpha_{i}+\varepsilon_{i t}$

productivity $_{i, t}=\beta_{0}+\beta_{1}$ firstyear $_{i, t-1}+\beta_{2} \ln l_{i, t-1}+\beta_{3} \ln k_{i, t-1}+\delta$ controls $_{i, t}+\alpha_{i}+\varepsilon_{i t}$

Instruments are employed in the second specification. Dummy firstyear is instrumented using an industry specific exchange rate and industry specific ratio of producer prices in the Czech Republic and abroad, their lags and year-on-year differences. ${ }^{11}$ By instrumenting the export entry indicator in the described way, I obtain the local average treatment effect of start to export for the firms that entered export markets due to changes in exchange rates or relative prices, i.e., due to clearly exogenous factors. Therefore, this estimate of learning-by-exporting disentangles productivity enhancements due to export entry induced by changes in relative prices and exchange rates and productivity enhancements of all other types, including the effect of a new manager as described in the introduction.

Export intensity varies substantially across firms and industries, as Figures 1 and 2 in the appendix illustrate. It is possible, that only firms with relatively high export intensity benefit from learning-by-exporting. Therefore, the specifications alternative to $(1,1 \mathrm{a}, 1 \mathrm{~b})$ are estimated, where the explanatory variable indicating the exporting status of a firm reflects the firm's export intensity instead of the exporting dummy. More specifically, variable firstyear_ei is equal to zero for non-exporters, while it is equal to the company's export intensity in the case of an export starter.

productivity $_{i, t}=\beta_{0}+\beta_{1}$ firstyear_ei $_{i, t}+\beta_{2} \ln l_{i, t-1}+\beta_{3} \ln k_{i, t-1}+\delta$ controls $s_{i, t}+\alpha_{i}+\varepsilon_{i t}$

\footnotetext{
${ }^{11}$ See chapter 4 for a detailed description of the construction of industry specific exchange rates and industry specific ratios of producer prices home and abroad.
} 


$$
\begin{aligned}
& \text { productivity }_{i, t}=\beta_{0}+\beta_{1} \text { firstyear_ei }_{i, t+1}+\beta_{2} \ln l_{i, t-1}+\beta_{3} \ln k_{i, t-1}+\delta \text { controls }_{i, t}+\alpha_{i}+\varepsilon_{i t} \\
& \text { productivity }_{i, t}=\beta_{0}+\beta_{1} \text { firstyear_ei }_{i, t-1}+\beta_{2} \ln l_{i, t-1}+\beta_{3} \ln k_{i, t-1}+\delta \text { controls }_{i, t}+\alpha_{i}+\varepsilon_{i t}
\end{aligned}
$$

As in the case of matching on propensity score, six productivity measures are used, i.e., levels and growth of labor productivity based on output, labor productivity based on value added and total factor productivity.

\section{Data and Descriptive Statistics}

Firm-level panel data are provided by the Czech Statistical Office. The sample of manufacturing firms covering the period 1997-2002 is employed. Firms that do not occur in the sample every year over the six-year period were eliminated. Also, due to the relatively small number of firms owned by municipalities, associations and cooperatives, those were eliminated as well. The industry of the firm is identified using its 3-digit NACE code, although I use the 2-digit NACE division in all cases except for the construction of industry specific exchange rates. Geographically, firms are divided into eight regions.

The ownership of a firm is defined as follows. If domestic private, domestic state or foreign owners control more than $50 \%$ of a firm, then the ownership indicator takes the value of private, state, or foreign, respectively. If a firm is owned by domestic owners only, but no ownership type controls more than $50 \%$, the ownership indicator takes the value of mixed. Finally, if foreign owners control not more than $50 \%$ of a firm, the ownership indicator is international. The baseline analysis employs only domestic private firms; the dataset of all firms is used in the robustness checks only. 
The reason is that foreign owned firms are likely to boost their productivity through knowledge and technology gained from the foreign owner rather then through learning-by-exporting. Numerous studies examine the effect of foreign owner on the performance and many find it positive and significant. The examples for the Czech Republic include Djankov and Hoekman (1999), Evenett and Voicu (2001) and Hanousek, Kocenda and Svejnar (2007). Not to mix these two effects, the learningby-exporting hypothesis is tested separately on the set of domestically owned firms, and, on the set of firms with foreign or international owner.

A firm is considered to be an exporter in a given year if the value of the firm's exports is greater than zero. Numbers of export starters as well as non-exporters in each industry and year are reported in Table 9 in the appendix. In order to eliminate false changes in export status that can emerge in the case of misreported value of exports, three alternative datasets are constructed. In the first dataset, firms that changed their export status for one year only (i.e., reported no export in one year while reported non-zero exports in both previous and following years or vice versa) are eliminated. In the remainder of the paper, this dataset is referred to as the baseline dataset. In the second dataset, all firms that changed their export status more than once over the sample period are eliminated. Finally, in the third dataset, no firms are eliminated. While results obtained using the baseline dataset are reported in section five, results obtained using two alternative datasets are compared as part of robustness checks in section six.

Two indexes are constructed to be used as instruments - industry specific exchange rate iser and industry specific ratio of producer prices in the Czech Republic and 
abroad isfp. Two datasets were combined constructing industry-specific exchange rates. Bilateral average yearly exchange rates for the Czech currency and currencies of its 26 main trading partners come from the database of the Czech National Bank. Detailed data on bilateral trade at the 3-digit SITC level were provided by the Ministry of Industry and Trade of the Czech Republic. Having SITC categories linked to NACE industry codes, industry specific exchange rates for each industry were constructed as the weighted average of exchange rate indexes with the weights based on the relative importance of export destinations. The value of index iser has been set such that iser is equal to 1 for each sector in 1997.

To construct isfp, sectoral producer price indexes of the 12 most important export destinations have been used in addition to bilateral exchange rates. For each country and each sector, the index of producer prices in local currency was constructed first. Subsequently, the index was recalculated into Czech currency using bilateral exchange rates and the ratio of domestic and foreign producer prices was constructed. Finally, the industry specific ratio of producer prices isfp was calculated for each industry as a weighted average of country and industry specific ratios with the weights of countries based on their relative importance as export destinations of Czech firms. The value of index isfp was set such that isfp is equal to 1 for each sector in 1997. Table 10 in the appendix shows the values of iser and isfp and their year-on-year differences averaged across the 2-digit NACE industry division. 
Table 1: The description of variables used

\begin{tabular}{|c|c|}
\hline Variable & Corresponding entry from CSO dataset \\
\hline Output & $\begin{array}{l}\text { Revenue from sales of own products and services }+ \text { change in inventories, adjusted for } \\
\text { inflation using industry-specific producer price index }\end{array}$ \\
\hline Labor & Average number of employees (recomputed on an eight hour day basis) \\
\hline Capital & Intangible and tangible fixed assets \\
\hline Investments & Purchase of intangible and tangible investment goods \\
\hline Export & Dummy equal to one if firm exports in respective year, zero otherwise \\
\hline Region & Regional dummies based on the division into eight regions \\
\hline Industry & Industry dummies based on 2-digit NACE codes \\
\hline Firstyear & $\begin{array}{l}\text { Dummy equal to one if firm exports in the respective year, but did not export in the } \\
\text { preceeding year. Zero otherwise. }\end{array}$ \\
\hline Firstyear_ei & $\begin{array}{l}\text { Variable equal to the ratio of firm's export and revenues if firm exports in the respective } \\
\text { year, but did not export in the preceeding year. Zero otherwise. }\end{array}$ \\
\hline Iser & Industry specific exchange rate \\
\hline Isfp & Industry specific ratio of producer prices in the Czech Republic and abroad \\
\hline Productivity & $\begin{array}{l}\text { Three productivity measures are employed: labor productivity based on output, labor } \\
\text { productivity based on value added and total factor productivity based on methodology } \\
\text { suggested by Levinsohn and Petrin (2000). Each measure is used in the level and growth } \\
\text { version. }\end{array}$ \\
\hline
\end{tabular}

\section{Results}

Unmatched productivity differences between export starters and non-exporters obtained using matching on propensity score approach suggest that the level of labor productivity of export-starters is significantly higher already before they start with exporting (Table 2). Once self selection into exporting is controlled for using matching on propensity score, the average treatment effect on exporters is positive and significant one year after export entry in the level specification. In the logic of previous research papers on learning-by-exporting, this would be considered as an indication of learning-by-exporting. However, as explained in the introduction, this can be also the effect of a new manager taking charge of a company, entering foreign markets and boosting productivity at the same time. Unmatched differences in growth rates of labor productivity based on output indicate no significant difference between non-exporters and export starters one year before export entry and in the year of export entry but significantly higher productivity one year later. In order not to mix 
the productivity enhancements gained through foreign owner and learning-byexporting effects, as explained later in the section six, only domestically owned firms are used in the baseline analysis. This reduction, however, decreases the sample size substantially and might negatively influence the standard errors and significance of estimated parameters.

Regression results in the Table 3 provide a different picture. Fixed effects panel data estimation without instruments suggest that both level and growth of the labor productivity based on output is significantly higher for export starters in the year of export entry. Once instruments are used to evaluate the productivity gains of firms that entered foreign markets due to an exogenous impetus, positive and significant differences diminish. This is in line with the self selection hypothesis and provides no support for learning-by-exporting theory.

Tables 2 and 3 provide results based on labor productivity of domestically owned non-exporters and export starters with changes in export status lasting longer than one year. Results based on the total factor productivity employing the same set of firms are provided in Tables 4 and 5 in the appendix. These provide more support for learning-by-exporting. Positive and significant average treatment effect on treated (i.e. export starters) one year after the export entry can be observed in the level specification in the Table 4. In addition, in the Table 5, fixed effects instrumental variable estimation on levels suggests positive and significant effects of learning-byexporting in case of firms that entered foreign markets due to exogenous impetus. Finally, results based on the sample of firms with foreign or international owner are provided in Tables 6 and 7 and discussed in section 6 . Table 8 in the appendix 
provides results of the estimation of the equations $(2,2 a$ and $2 b)$, i.e. the estimation employing export intensity of export starters. This specification, however, provides no evidence of significant differences between the productivity of non-exporters and export starters.

\section{Learning-by-Exporting and the Effect of Ownership}

As outlined in the introduction, a firm's ownership can affect the potential for learning-by-exporting. A firm controlled by a foreign owner is likely to have access to technology and know-how directly from the foreign owner. For such a firm, the potential for learning by exporting is narrow. However, learning-by-exporting can be an important channel for productivity increases in the case of a firm with a domestic owner.

The issue of ownership is tackled as follows. The effect of learning-by-exporting is estimated separately on the sample of firms with a domestic private owner and on the sample of firms with foreign or international owner. In line with expectations, an analysis employing the sample of firms with foreign and international owners provides no significant differences in productivity between non-exporters and export starters at all (Tables 6 and 7). This likely reflects the fact that foreign owned firms are in general more productive than domestically owned firms thanks to access to know-how of foreign owners. However, caution is needed as no significance can be also the result of very small sample size of non-exporters and export starters with foreign or international owner. 


\section{Robustness Checks}

A number of robustness checks are performed to examine how sensitive the results are to different specifications. First, three measures of productivity are used: labor productivity based on output, labor productivity based on value added and total factor productivity. Second, I look at the effects of exporting at both levels and growth rates of productivity measures.

The other robustness issue emerges from the possible miscoding in the definition of being an exporter. As indicated in section four, only firms that are observed in all 6 years are included in the dataset. For each year, firms with the exports higher than zero are coded as exporters, firms with zero export as non-exporters. As a result, about $20 \%$ of all firms do change their exporting status at least once during the six year period. There is, however, a risk that exports of some firms were not recorded correctly every year and transition between exporting and non-exporting in case of these firms is just artificial. The most prominent candidates for this group would be firms which did not export only in one year. To examine how this type of miscoding could have influenced the results, I construct three alternative data sets. In the first alternative dataset, all firms which changed their exporting status for one year only are eliminated. In the second dataset, all firms are included. In the third alternative dataset, all firms that changed exporting status more than once are eliminated.

Comparison of the results based on labor productivity gained using three alternative datasets suggests that the results are robust in the sense that the magnitude and significance of coefficients are comparable across three datasets. 
Table 2: Productivity level and productivity growth differences between export starters and non-exporters: matching on propensity score approach, firms with domestic owners

\section{Labor productivity based on output}

\begin{tabular}{|c|c|c|c|c|c|c|}
\hline & \multicolumn{3}{|c|}{ Level } & \multicolumn{3}{|c|}{ Growth } \\
\hline Number of controls & 237 & 238 & 235 & 159 & 238 & 234 \\
\hline Standard Error & $(2.23)$ & $(2.21)$ & $(2.26)$ & $(0.08)$ & $(0.07)$ & $(0.11)$ \\
\hline Average treatment effect on treated & 2.73 & 3.66 & 5.49 * & -0.11 & 0.12 & 0.47 \\
\hline Standard Error & $(2.79)$ & $(2.96)$ & $(3.03)$ & $(0.13)$ & $(0.07)$ & $(0.36)$ \\
\hline
\end{tabular}

Labor productivity based on value added

\begin{tabular}{|c|c|c|c|c|c|c|}
\hline & \multicolumn{3}{|c|}{ Level } & \multicolumn{3}{|c|}{ Growth } \\
\hline & One year before & Year of entry & One year after & One year before & Year of entry & One year aftel \\
\hline Number of controls & 235 & 238 & 232 & 159 & 238 & 234 \\
\hline Standard Error & $(2.21)$ & $(2.09)$ & $(2.15)$ & $(0.12)$ & $(0.72)$ & $(0.81)$ \\
\hline Average treatment effect on treated & -0.76 & -0.19 & 0.97 & 0.02 & 0.29 & -2.50 \\
\hline Standard Error & $(4.18)$ & $(2.55)$ & $(3.18)$ & $(0.10)$ & $(0.46)$ & $(2.96)$ \\
\hline
\end{tabular}


Table 3: Productivity level and productivity growth differences between export starters and non-exporters: regression approach, firms with domestic owners

Labor productivity based on output

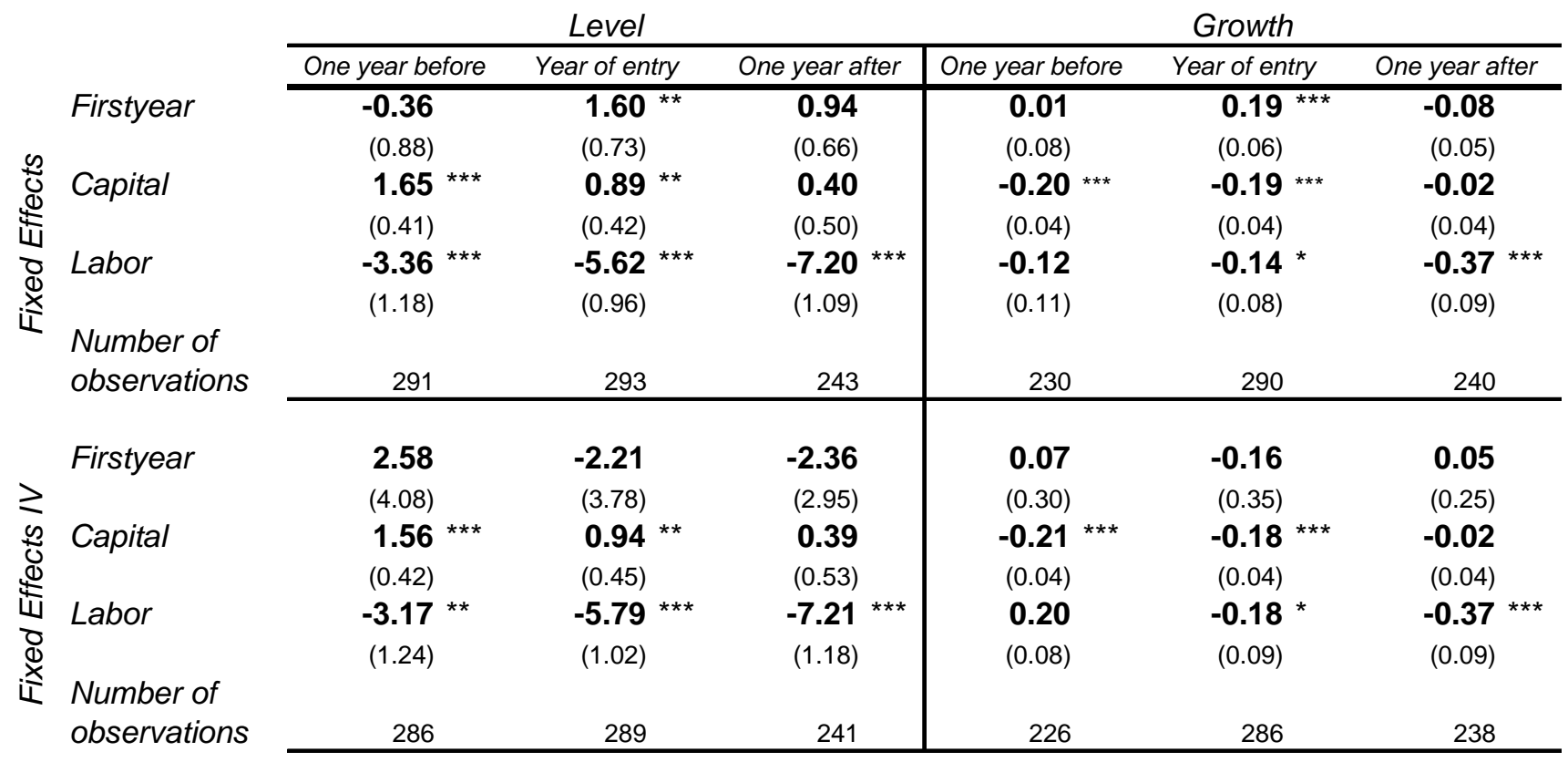

Labor productivity based on value added

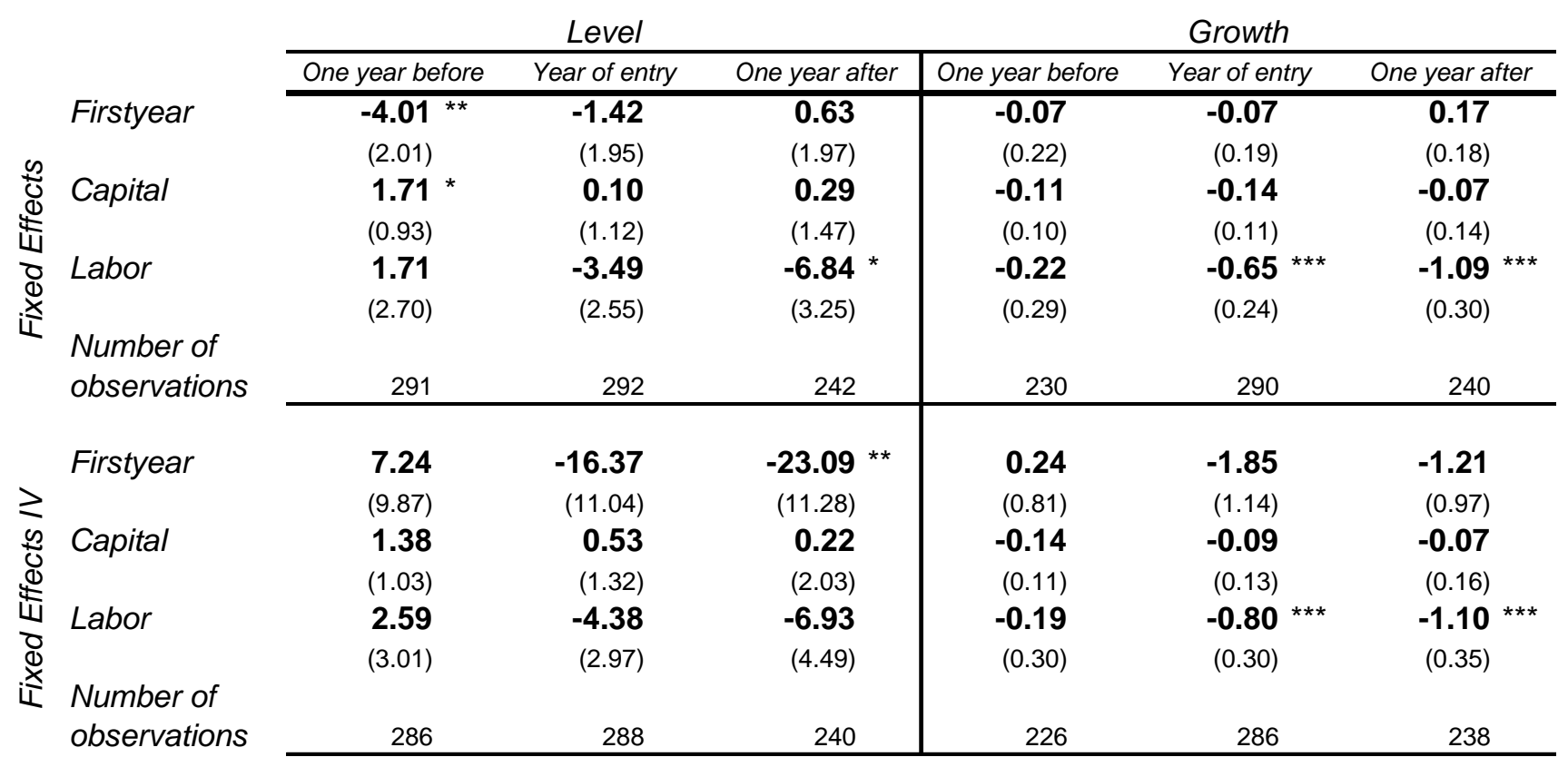

Notes: Dependent variables are the logarithms of the levels and growth rates of respective productivity measures. Besides the indicator of the export entry, variable firstyear, explanatory variables include logarithms of capital and labor as well as region dummies and a constant. 


\section{Conclusion}

The effect of exporting on productivity is estimated using firm-level panel data from the Czech Republic. In addition to matching on propensity score, I estimate the local average treatment effect of export entry on the productivity of firms that started with exporting due to exogenous impetus, such as changes in industry-specific exchange rates and industry-specific ratios of producer prices on domestic and foreign market. In this way, I disentangle learning-by-exporting from changes in firm management that bring the firm to enter foreign markets and introduce productivity increasing measures at the same time. Despite relatively important differences in productivity levels between the Czech Republic and most of its export destinations, the results of both methods provide only limited evidence of the learning-by-exporting effect in the case of Czech exporters. 


\section{References}

Arnold, J.M., Hussinger, K. 2005. Export Behavior and Firm Productivity in German Manufacturing. A Firm-Level Analysis. Review of World Economics/ Weltwirtschaftliches Archiv 141(2): $219-243$.

Aw, B.Y., Chung, S., Roberts, M.J. 2000. Productivity and Turnover in the Export Market: Microlevel Evidence from the Republic of Korea and Taiwan (China). World Bank Economic Review 14(1): 65-90.

Bernard, A.B., Jensen J. B. 1999. Exceptional Exporter Performance: Cause, Effect, or Both? Journal of International Economics 47: 1-25.

Bernard, A.B., Wagner, J. 1998. Export Entry and Exit by German Firms. NBER Working Papers 6538, National Bureau of Economic Research, Inc.

Bigsten, A., Collier, P., Dercon, S., Fafchamps, M., Gauthier, B., Gunning, J.W., Oduro, A., Oostendorp, R., Pattillo, C., Söderbom, M., Teal, F., Zeufack, A. 2004. Do African Manufacturing Firms Learn from Exporting? Journal of Development Studies 40(3): 115-141.

Bleaney, M.F., Filatotchev, I., Wakelin, K. 2000. Learning by Exporting: Evidence from Three Transition Economies. Centre for Research on Globalisation and Labour Markets, School of Economics, University of Nottingham, Research Paper 2000/6.

Castellani, D. 2002. Export Behavior and Productivity Growth: Evidence from Italian Manufacturing Firms. Weltwirtschaftliches Archiv 138(4).

Caliendo, M., Kopeinig, S. 2005. Some Practical Guidance for the Implementation of Propensity Score Matching. Discussion Papers of DIW Berlin 485, DIW Berlin, German Institute for Economic Research.

Clerides, S.K., Lach, S., Tybout, J.R. 1998. Is Learning by Exporting Important? Micro-dynamic Evidence from Colombia, Mexico and Morocco. Quarterly Journal of Economics 113: 903-948. 
Delgado, M., Farinas, J.C., Ruano, S. 2002. Firm Productivity and Export Markets: A Nonparametric Approach. Journal of International Economics 57: 397-422.

Djankov, S., Hoekman, B. 2000. Foreign Investment and Productivity Growth in Czech Enterprises. World Bank Economic Review, Vol. 14, pp. 49-64.

Evenett, S.J., Voicu, A. 2001. Picking Winners or Creating Them? Revisiting the Benefits of FDI in the Czech Republic? Mimeo, the World Bank.

Girma, S., Greenaway, D., Kneller, R. 2004. Does Exporting Increase Productivity? A Microeconometric Analysis of Matched Firms. Review of International Economics 12 (5): 855-866.

Hallward-Driemeier, M., Iarossi, G., Sokoloff, K.L. 2002. Exports and Manufacturing Productivity in East Asia: A Comparative Analysis with Firm-Level Data. NBER Working Papers 8894, National Bureau of Economic Research, Inc.

Hanousek, J., Kocenda, E., Svejnar, J. 2007. Origin and concentration: Corporate ownership, control and performance in firms after privatization. Economics of Transition, Volume 15(1) 2007, 131

Head, K., Ries, J. 2003. Heterogeneity and the FDI versus Export Decision of Japanese Manufacturers. NBER Working Papers 10052, National Bureau of Economic Research, Inc.

Isgut, A. 2001. What's Different about Exporters? Evidence from Colombian Manufacturing. Journal of Development Studies 37 (5): 57-82.

Leuven E., Sianesi, B. 2003. PSMATCH2: Stata module to perform full Mahalanobis and propensity score matching, common support graphing and covariate imbalance testing.

Http://ideas.repec.org/c/boc/bocode/s432001.html. This version 3.0.0.

Levinsohn, J., Petrin, A. 2000. Estimating Production Functions Using Inputs to Control for Unobservables. Review of Economic Studies 70(2): 317-341.

Petrin, A., Poi, B.P., Levinsohn, J. 2004. Production function estimation in Stata using inputs to control for unobservables. Stata Journal, 4(2): 113-123. 
Olley, G.S., Pakes A. 1996. The Dynamics of Productivity in the Telecommunications Equipment Industry. Econometrica 64(6): 1263-1297.

Pavcnik, N. 2002. Trade liberalization, exit, and productivity improvements: Evidence from Chilean plants. Review of Economic Studies 69(1): 245-276

Roberts, M., Tybout, J. 1997. The Decision to Export in Colombia: An Empirical Model of Entry with Sunk Costs. American Economic Review 87(4): 545-564.

Sabirianova, K., Svejnar, J., Terrell, K. 2005. Foreign Investment, Corporate Ownership, and Development: Are Firms in Emerging Markets Catching Up to the World Standard? William Davidson Institute Working Paper No. 734.

Wagner, J. 2002. The Causal Effects of Exports on Firm Size and Labor Productivity: First Evidence from a Matching Approach. Economic Letters 77: 287-292. 


\section{Appendix}

Table 4: Productivity level and productivity growth differences between export starters and non-exporters: matching on propensity score approach, firms with domestic owners

\begin{tabular}{|c|c|c|c|c|c|c|}
\hline & \multicolumn{6}{|c|}{ Total factor productivity } \\
\hline & \multicolumn{3}{|c|}{ Level } & \multicolumn{3}{|c|}{ Growth } \\
\hline Number of starters & 19 & 19 & 20 & 17 & 18 & 18 \\
\hline Unmatched difference & -81.51 & $604.82 * \star \star$ & 93.63 & -0.03 & -0.06 & -0.03 \\
\hline Standard Error & (58.82) & $(129.94)$ & (83.89) & $(0.04)$ & $(0.03)$ & $(0.03)$ \\
\hline Average treatment effect on treated & -104.51 & 576.57 & 81.43 * & -0.04 & -0.05 & -0.05 \\
\hline Average treatment effect & -111.62 & 460.74 & 99.66 & -0.01 & -0.01 & 0.00 \\
\hline
\end{tabular}


Table 5: Productivity level and productivity growth differences between export starters and nonexporters: regression approach, firms with domestic owners

Total factor productivity

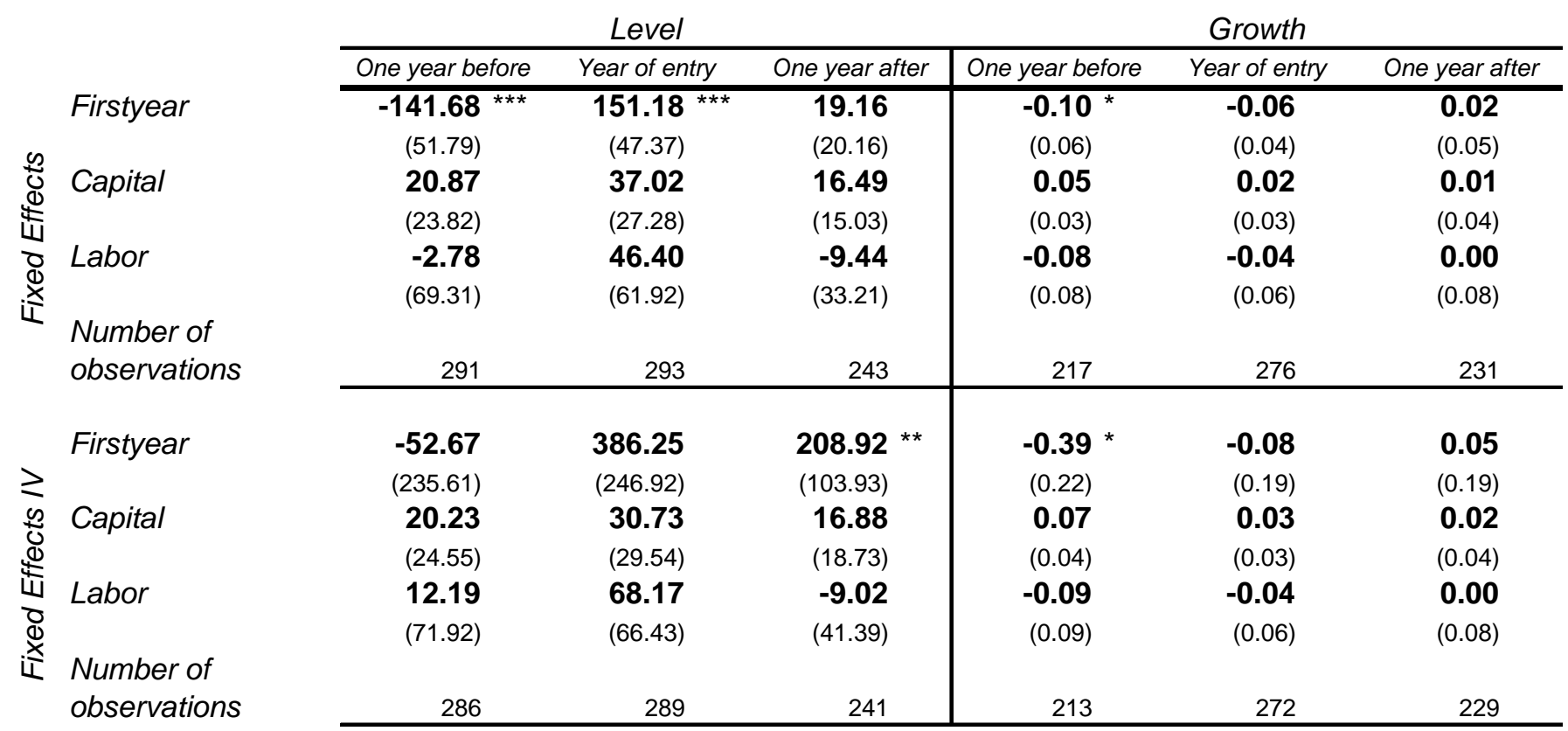

Notes: Dependent variables are the logarithms of the levels and growth rates of respective productivity measures. Besides the indicator of the export entry, variable firstyear, explanatory variables include logarithms of capital and labor as well as region dummies and a constant. 
Table 6: Productivity level and productivity growth differences between export starters and non-exporters: matching on propensity score approach, firms with foreign or international owners

\section{Labor productivity based on output}

\begin{tabular}{|c|c|c|c|c|c|c|}
\hline & \multicolumn{3}{|c|}{ Level } & \multicolumn{3}{|c|}{ Growth } \\
\hline & One year before & Year of entry & One year after & One year before & Year of entry & One year after \\
\hline Number of starters & 8 & 8 & 3 & 6 & 8 & 3 \\
\hline Number of controls & 21 & 20 & 22 & 21 & 20 & 22 \\
\hline Unmatched difference & 0.83 & 1.56 & 5.41 & 0.17 & 0.15 & 0.12 \\
\hline Standard Error & $(4.51)$ & $(5.14)$ & $(6.28)$ & $(0.10)$ & $(0.13)$ & $(0.17)$ \\
\hline Average treatment effect on treated & -1.45 & 0.54 & -12.21 & 0.20 & 0.17 & 0.22 \\
\hline Standard Error & $(8.28)$ & $(8.01)$ & $(16.16)$ & $(0.20)$ & $(0.23)$ & $(0.56)$ \\
\hline Average treatment effect & -1.99 & 4.61 & 2.10 & 0.14 & 0.09 & 0.82 \\
\hline
\end{tabular}

\section{Labor productivity based on value added}

\begin{tabular}{|c|c|c|c|c|c|c|}
\hline & \multicolumn{3}{|c|}{ Level } & \multicolumn{3}{|c|}{ Growth } \\
\hline & One year before & Year of entry & One year after & One year before & Year of entry & One year after \\
\hline Number of starters & 8 & 9 & 3 & 6 & 8 & 3 \\
\hline Number of controls & 22 & 19 & 22 & 21 & 20 & 22 \\
\hline Unmatched difference & 2.25 & 2.52 & 4.73 & 0.25 & 0.33 & 0.43 \\
\hline Standard Error & $(4.02)$ & $(4.79)$ & $(5.40)$ & $(0.40)$ & $(0.39)$ & $(0.46)$ \\
\hline Average treatment effect on treated & 0.23 & -8.70 & -2.78 & 0.10 & -0.04 & 0.63 \\
\hline Standard Error & $(7.35)$ & $(6.22)$ & $(6.58)$ & $(0.16)$ & $(0.12)$ & $(0.67)$ \\
\hline Average treatment effect & 0.56 & -0.75 & 1.97 & 0.02 & 0.01 & 1.37 \\
\hline
\end{tabular}


Table 7: Productivity level and productivity growth differences between export starters and non-exporters: regression approach, firms with foreign or international owners

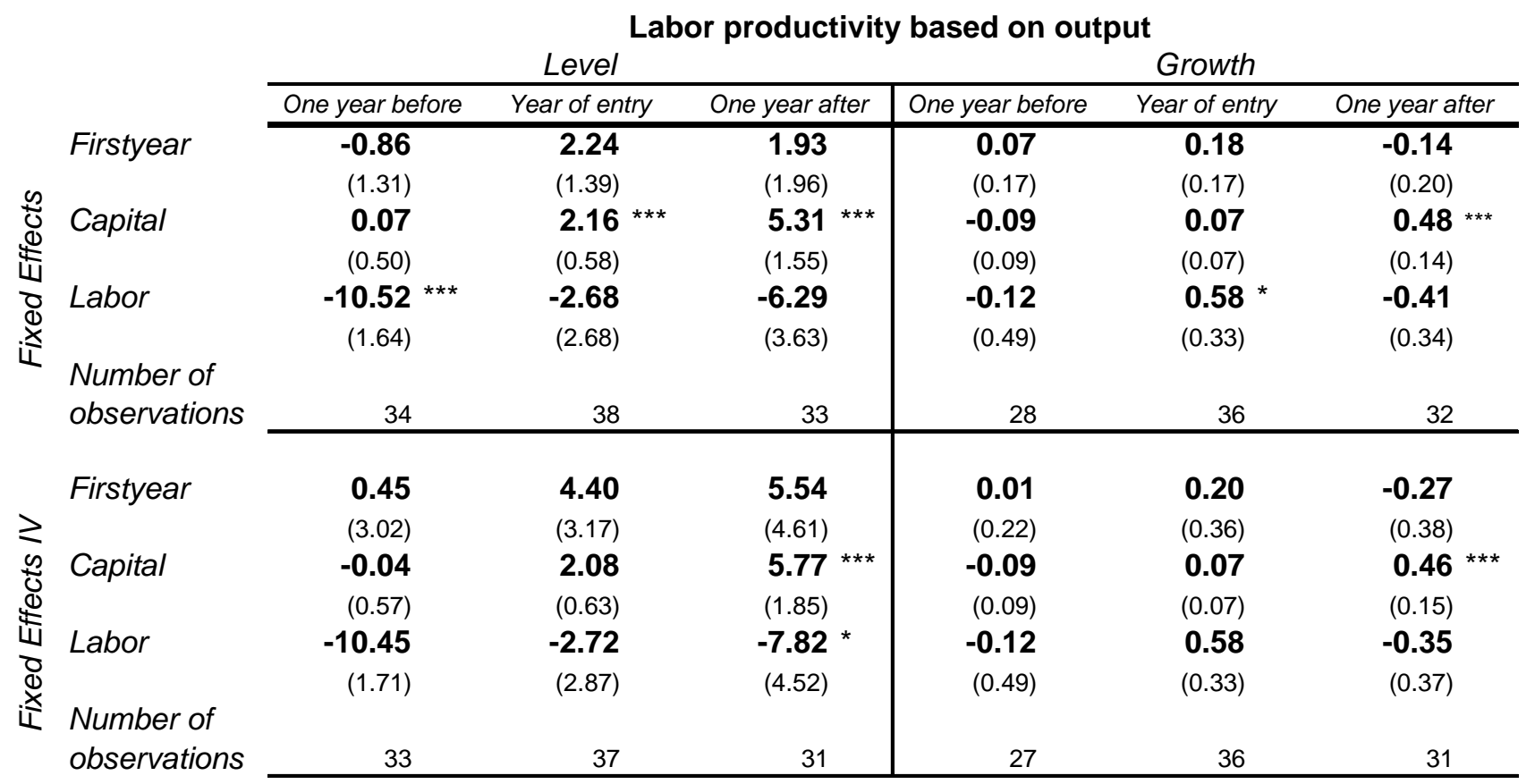

\section{Labor productivity based on value added}

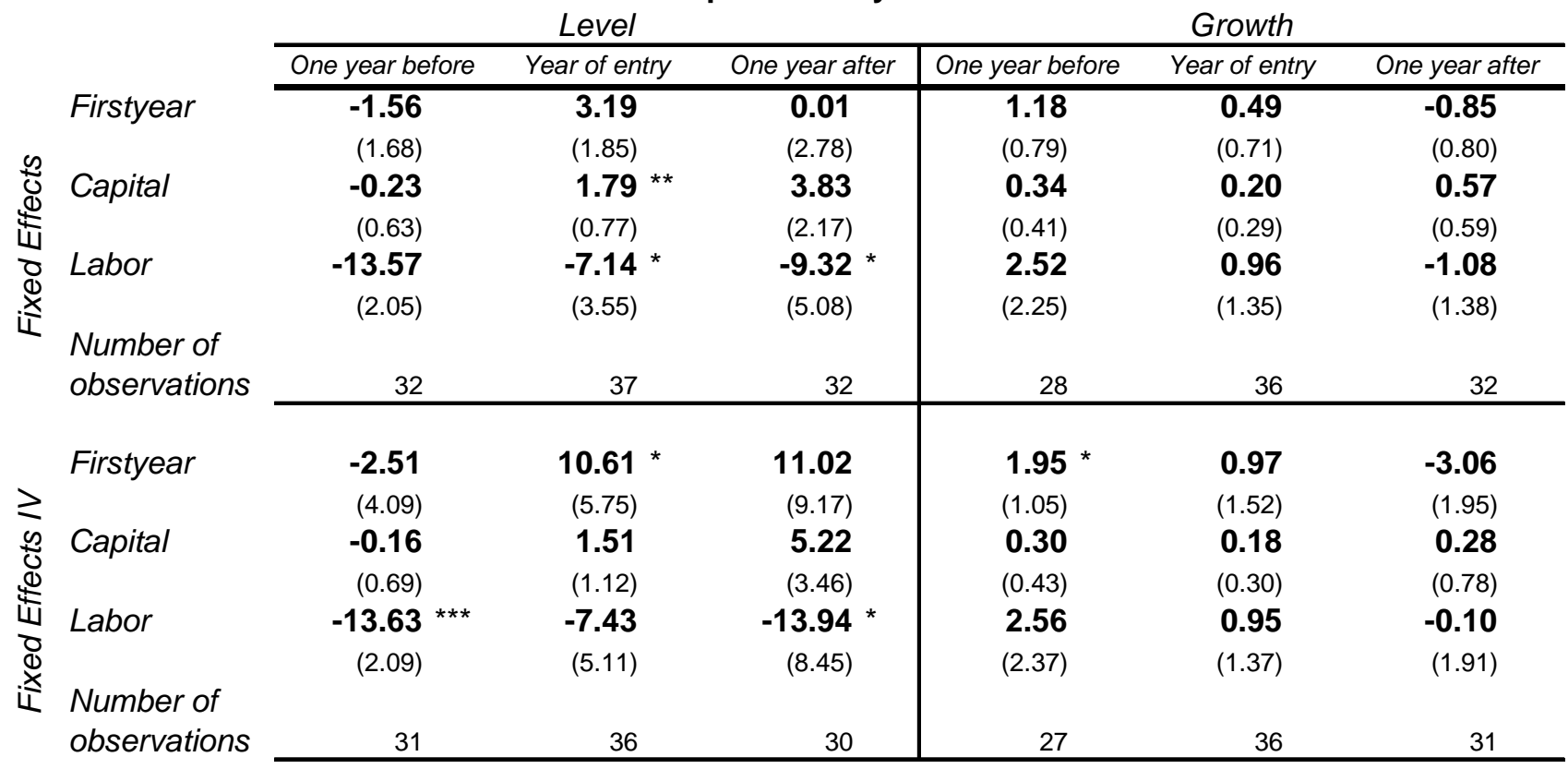

Notes: Dependent variables are the logarithms of the levels and growth rates of respective productivity measures. Besides the indicator of the export entry, variable firstyear, explanatory variables include logarithms of capital and labor as well as region dummies and a constant. 
Table 8: Productivity level and productivity growth differences between export starters and non-exporters: regression approach with export intensity, firms with domestic owners

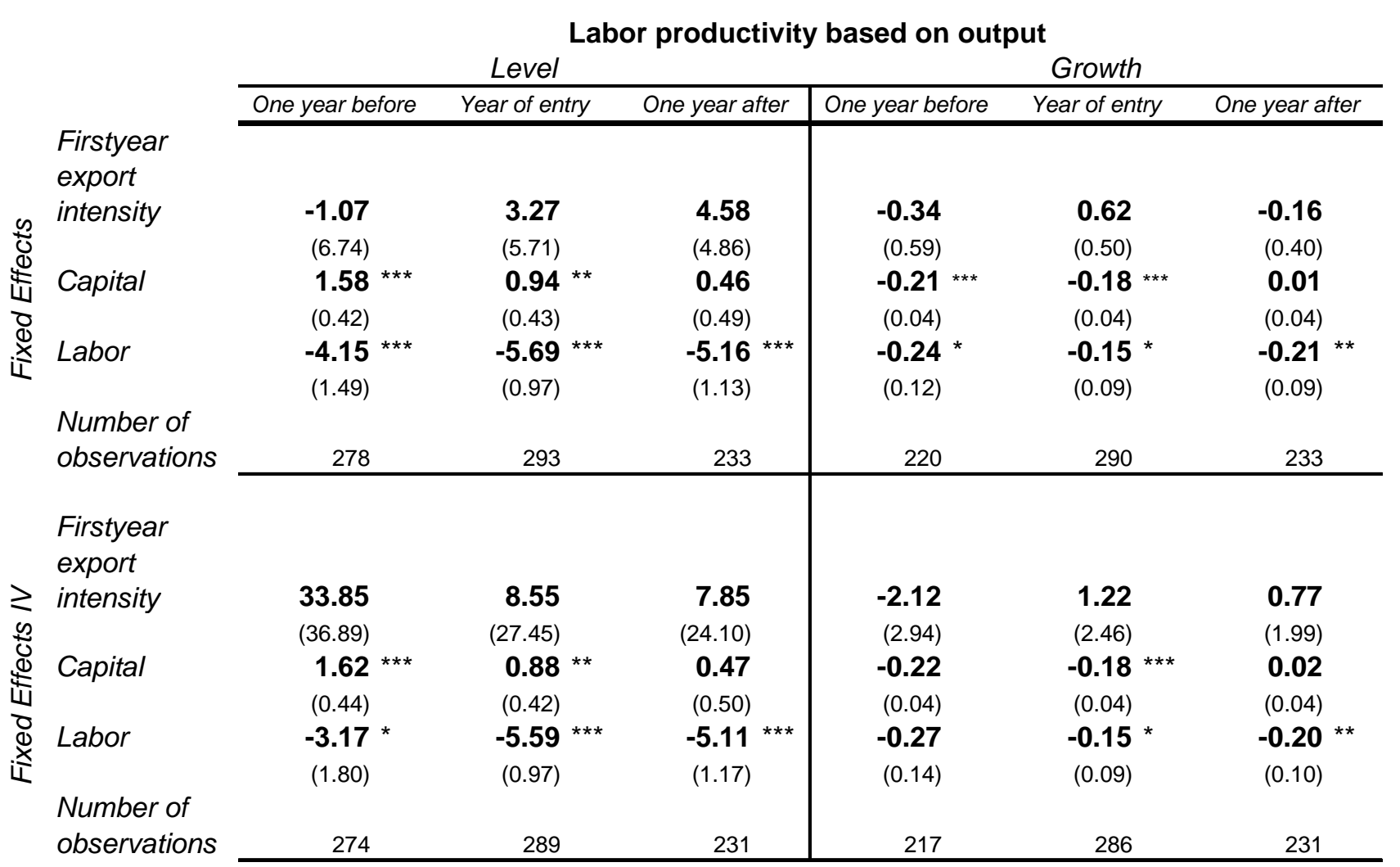

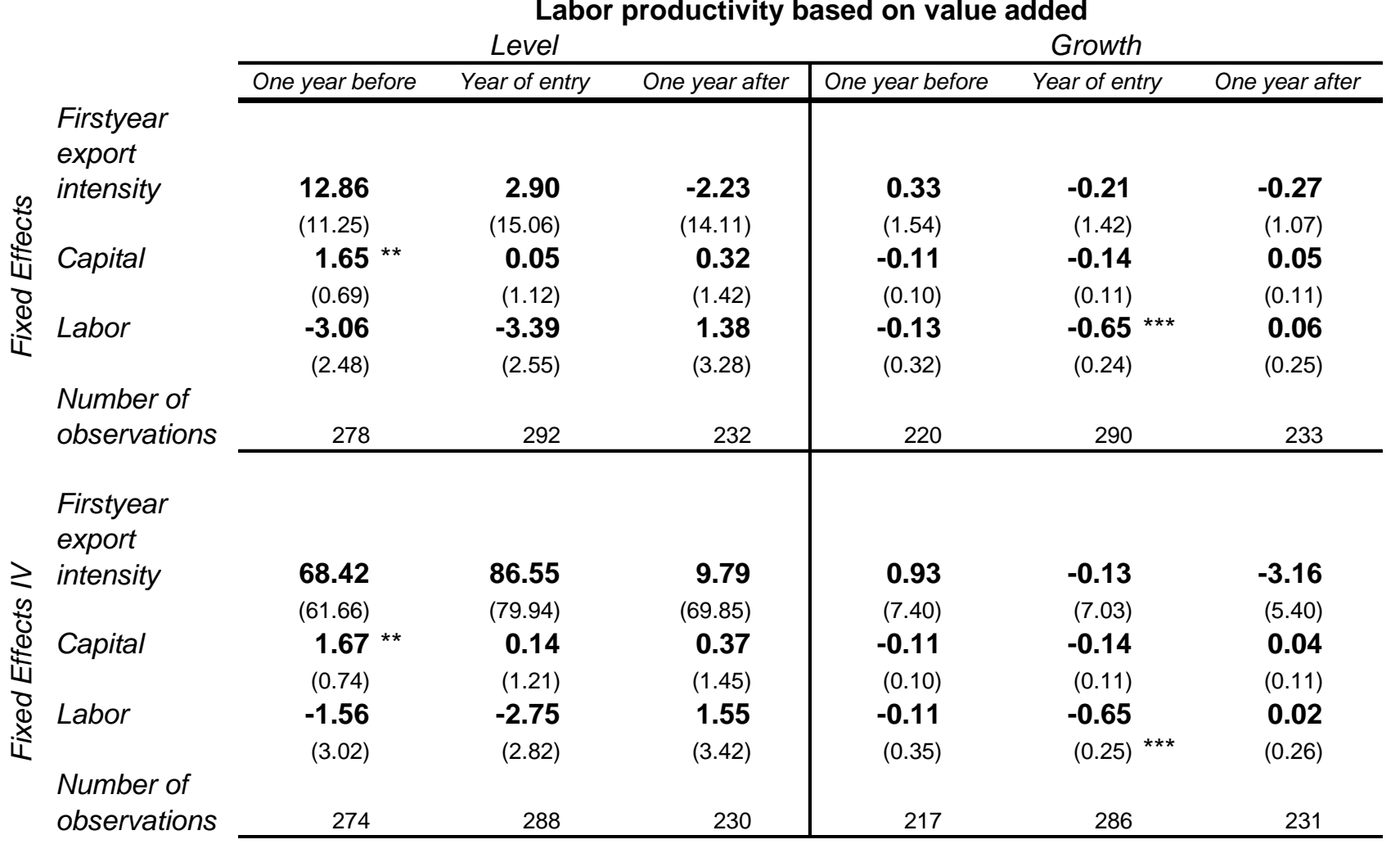

Notes: Dependent variables are the logarithms of the levels and growth rates of respective productivity measures. Besides the indicator of the export entry and export intensity, explanatory variables include logarithms of capital and labor as well as region dummies and a constant. 
Table 9: Number of export starters and number of non-exporters by industry and year

\begin{tabular}{|c|c|c|c|c|c|c|c|c|c|c|}
\hline & \multicolumn{2}{|c|}{1998} & \multicolumn{2}{|c|}{1999} & \multicolumn{2}{|c|}{2000} & \multicolumn{2}{|c|}{2001} & \multicolumn{2}{|c|}{2002} \\
\hline & $\begin{array}{l}\text { export } \\
\text { starters }\end{array}$ & $\begin{array}{c}\text { non- } \\
\text { exporters }\end{array}$ & $\begin{array}{l}\text { export } \\
\text { starters }\end{array}$ & $\begin{array}{c}\text { non- } \\
\text { exporters }\end{array}$ & $\begin{array}{l}\text { export } \\
\text { starters }\end{array}$ & $\begin{array}{c}\text { non- } \\
\text { exporters }\end{array}$ & $\begin{array}{l}\text { export } \\
\text { starters }\end{array}$ & $\begin{array}{c}\text { non- } \\
\text { exporters }\end{array}$ & $\begin{array}{l}\text { export } \\
\text { starters }\end{array}$ & $\begin{array}{c}\text { non- } \\
\text { exporters }\end{array}$ \\
\hline Food products and beverages & 11 & 75 & 9 & 72 & 18 & 62 & 12 & 65 & 9 & 68 \\
\hline Tobacco products & & 1 & & 1 & 1 & 1 & & 1 & & 1 \\
\hline Textiles & 1 & 8 & 7 & 5 & 2 & 4 & 1 & 7 & 2 & 10 \\
\hline Wearing apparel; dressing and dyeing of fur & 2 & 4 & 2 & 3 & & 5 & 4 & 3 & 1 & 3 \\
\hline Leather and leather products & 4 & & & 1 & 2 & & 1 & & 1 & 3 \\
\hline Wood and of products of wood and cork, except furniture & 1 & 3 & 5 & 2 & & 3 & 1 & 4 & 3 & 8 \\
\hline Pulp, paper and paper products & 4 & 5 & 4 & 3 & & 3 & 2 & 4 & 1 & 4 \\
\hline $\begin{array}{l}\text { Publishing, printing and reproduction of recorded media } \\
\text { Coke, refined petroleum products and nuclear fuel }\end{array}$ & 5 & 13 & 7 & 12 & 6 & 10 & 3 & 11 & 5 & 13 \\
\hline Chemicals and chemical products & 2 & 7 & 5 & 6 & 4 & 4 & 1 & 4 & 1 & 4 \\
\hline Rubber and plastic products & 2 & 2 & 1 & 4 & 1 & 3 & & 5 & 1 & 5 \\
\hline Other non-metallic mineral products & 1 & 9 & 3 & 9 & 2 & 8 & 1 & 8 & 2 & 7 \\
\hline Basic metals & 4 & 4 & 9 & 2 & 2 & 2 & 1 & 4 & 1 & 5 \\
\hline Fabricated metal products, except machinery and equipment & 5 & 7 & 6 & 4 & & 4 & 3 & 5 & 2 & 8 \\
\hline Machinery and equipment n.e.c. & 4 & 9 & 5 & 6 & 3 & 4 & 1 & 4 & 1 & 4 \\
\hline Office machinery and computers & & 1 & 1 & & & & & & 1 & \\
\hline electrical machinery and apparatus n.e.c. & 5 & 11 & 4 & 10 & 4 & 7 & 3 & 10 & 2 & 15 \\
\hline Radio, television and communication equipment and apparatus & 5 & 6 & 6 & 2 & & 3 & 1 & 3 & 3 & 6 \\
\hline Medical, precision and optical instruments, watches and clocks & 2 & 5 & 5 & 3 & 1 & 4 & 2 & 5 & 3 & 6 \\
\hline Motor vehicles, trailers and semi-trailers & 1 & 2 & 4 & & 1 & & & 1 & & 1 \\
\hline Other transport equipment & 2 & 4 & 5 & 1 & & 1 & 1 & 5 & & 7 \\
\hline Furniture; manufacturing n.e.c. & 3 & 3 & 3 & 1 & 1 & 2 & 1 & 3 & 1 & 2 \\
\hline Recycling & & 4 & 3 & 4 & & 4 & & 5 & 1 & 9 \\
\hline
\end{tabular}


Table 10: Industry specific exchange rates and producer price ratios

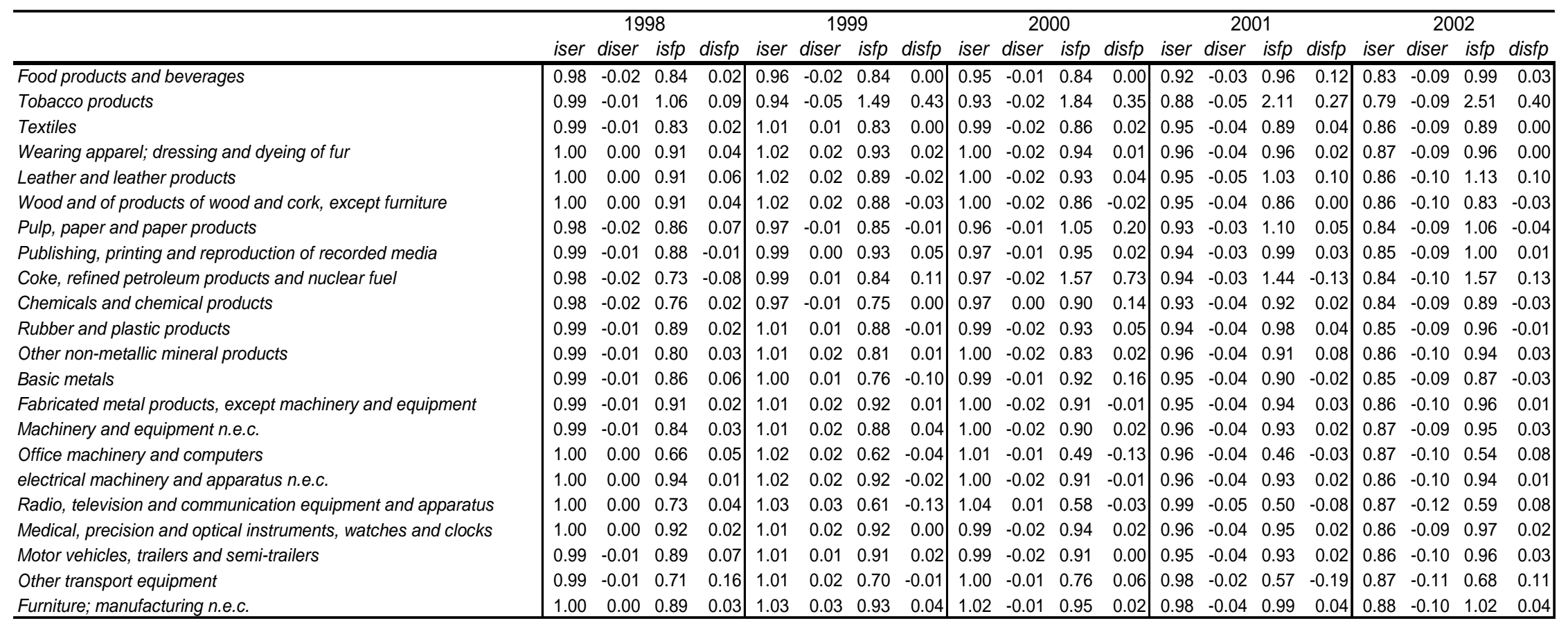

Note: Iser denotes industry specific exchange rate. Isfp denotes industry specific producer price ratio. Diser and Disfp are their respective year-on-year differences. 
Figure 1: Histograms of export intensity (for individual industries)

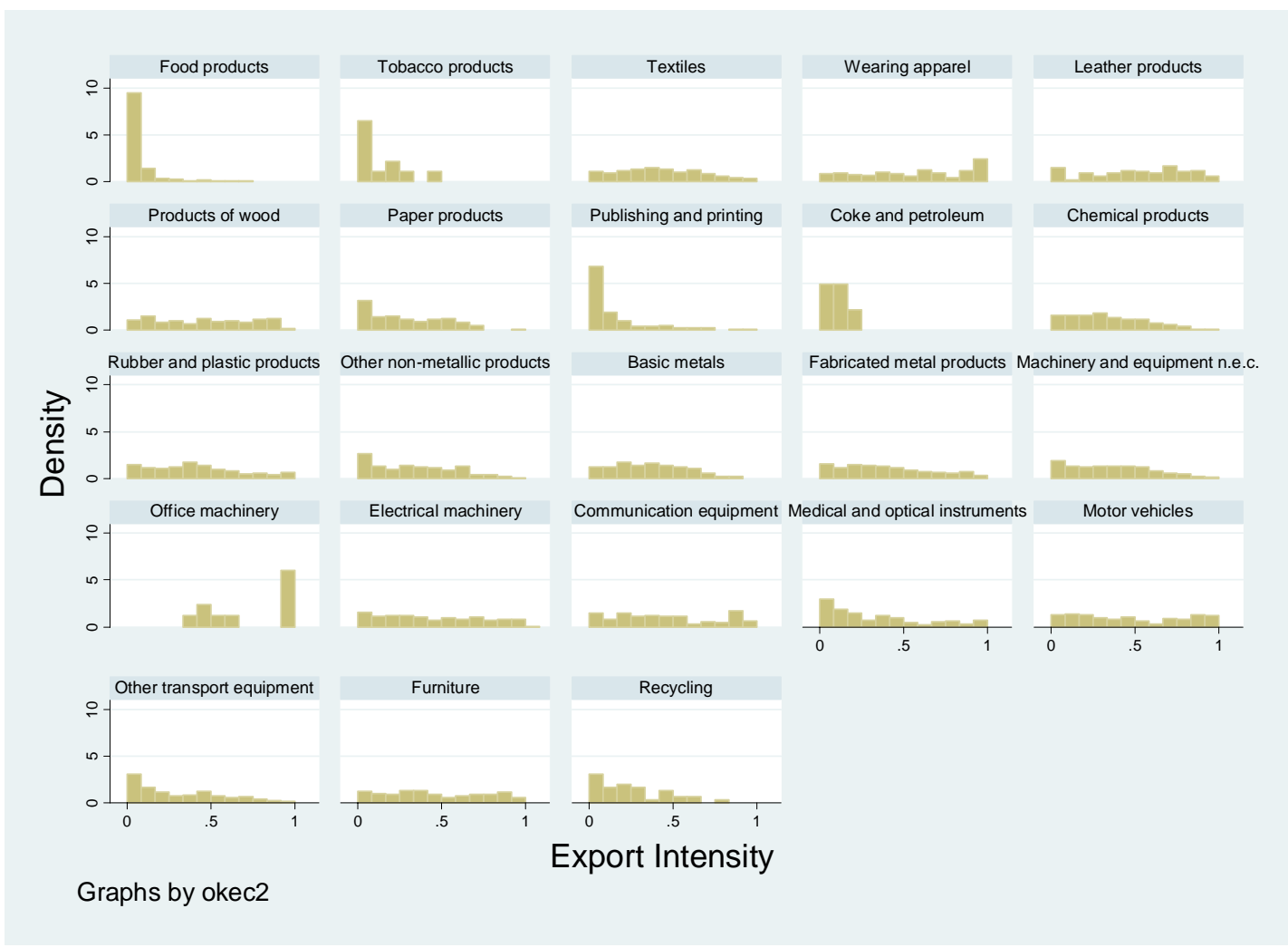

Figure 2: Evolution of export intensity across time (for individual industries)

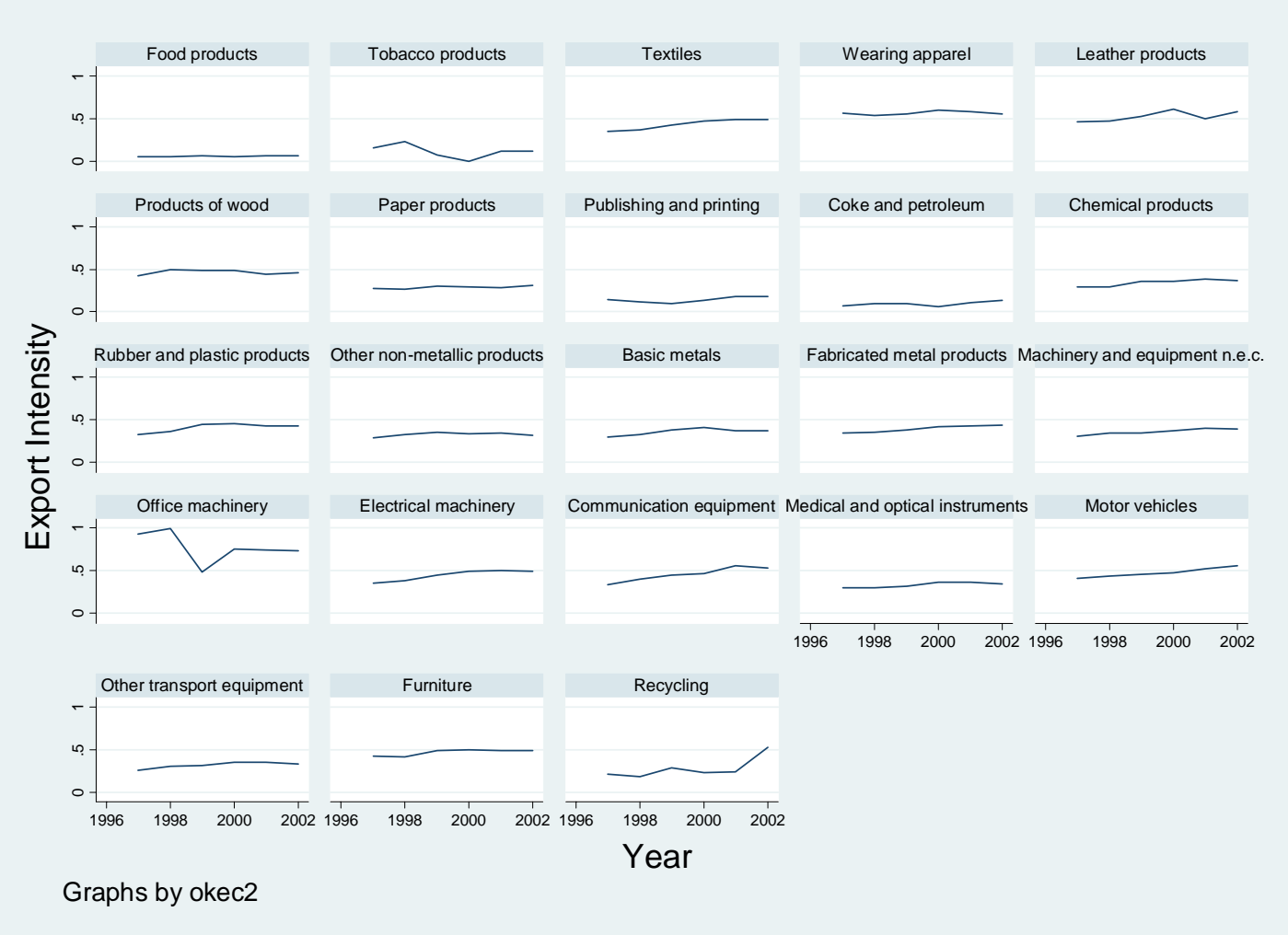


Individual researchers, as well as the on-line and printed versions of the CERGE-EI Working Papers (including their dissemination) were supported from the following institutional grants:

- Center of Advanced Political Economy Research [Centrum pro pokročilá politickoekonomická studia], No. LC542, (2005-2009),

- Economic Aspects of EU and EMU Entry [Ekonomické aspekty vstupu do Evropské unie a Evropské měnové unie], No. AVOZ70850503, (2005-2010);

- Economic Impact of European Integration on the Czech Republic [Ekonomické dopady evropské integrace na ČR], No. MSM0021620846, (2005-2011);

Specific research support and/or other grants the researchers/publications benefited from are acknowledged at the beginning of the Paper.

(c) Branislav Saxa, 2008

All rights reserved. No part of this publication may be reproduced, stored in a retrieval system or transmitted in any form or by any means, electronic, mechanical or photocopying, recording, or otherwise without the prior permission of the publisher.

Published by

Charles University in Prague, Center for Economic Research and Graduate Education (CERGE) and

Economics Institute ASCR, v. v. i. (EI)

CERGE-El, Politických vězňů 7, 11121 Prague 1, tel.: +420 224005 153, Czech Republic.

Printed by CERGE-EI, Prague

Subscription: CERGE-EI homepage: http://www.cerge-ei.cz

Editors: Directors of CERGE and EI

Managing editors: Deputy Directors for Research of CERGE and EI

ISSN 1211-3298

ISBN 978-80-7343-158-7 (Univerzita Karlova. Centrum pro ekonomický výzkum

a doktorské studium)

ISBN 978-80-7344-147-0 (Národohospodářský ústav AV ČR, v. v. i.) 
CERGE-EI

P.O.BOX 882

Politických vězňů 7

11121 Praha 1

Czech Republic http://www.cerge-ei.cz 